\title{
DAMPAK PENYALURAN DANA INFAK SEBAGAI MODAL USAHA DALAM PEMBERDAYAAN EKONOMI ANGGOTA (STUDI KASUS PADA PROGRAM KOMUNITAS USAHA MANDIRI (KUM) YAYASAN DANA SOSIAL AL-FALAH SURABAYA)"]
}

\author{
Elita Sri Arumningtyas \\ Program Studi Ekonomi Islam-Fakultas Ekonomi dan Bisnis-Universitas Airlangga \\ Email: elita.sri-12@feb.unair.ac.id \\ Suherman Rosyidi \\ Departemen Ekonomi Syariah-Fakultas Ekonomi dan Bisnis-Universitas Airlangga \\ Email: srosyidi@gmail.com
}

\begin{abstract}
This goal of the research is to determine the effect of lending capital which come from creative-productive infaq for the members of Komunitas Usaha Mandiri, a program run by Yayasan Dana Sosial al-Falah. This research uses descriptive qualitative design and case study methods. The data was collected through field observations, interviews, and a documentation of four members in the Komunitas Usaha Mandiri program in Surabaya city. The result shows that four informen had been experiencing the improvement of their sales turnover, profit, and the availability of goods after they got the working capital. A sustainable agenda and a set of training which conduted by KUM program were felt to be useful to enrich their religion base knowledge and the ability of enterpreneurship. Moreover, they were able to save and pay for infaq. So, it could be concluded that Komunitas Usaha Mandiri program has successfully develop the members business.
\end{abstract}

Keywords : Infaq, Micro Business, Management of Zakat, Economy Empowerment

\section{Pendahuluan}

Kemiskinan telah menjadi salah satu persoalan krusial yang dihadapi oleh seluruh negara berkembang, termasuk negara Indonesia. Secara singkat, kemiskinan diartikan sebagai rendahnya tingkat pendapatan atau konsumsi sebuah keluarga untuk memenuhi kebutuhan hidup sehari-hari. Terbatasnya lapangan kerja yang disediakan oleh lembaga pemerintahan maupun swasta dan distribusi pendapatan yang tidak merata menimbulkan adanya ketimpangan sosial di kehidupan masyarakat.

Islam sangat memerangi kemiskinan demi menghindari bahayanya terhadap akidah, akhlak, dan perilaku umat muslim. Hal ini dapat mengganggu pikiran dan menimbulkan prasangka buruk kepada siapapun, terutama kepada Allah SWT. Rasulullah SAW bersabda:

$$
\text { كادَالْفَتُرأَنْ يَّكُوْنَ كُفْرًا (ابونسيم من انس) }
$$

$K a>d a$ 'l-faqru an-yaku>na kufra $>n$.

"Kefakiran (kemiskinan) itu nyaris menyebabkan kekafiran". (HR. Abu Nu'aim dalam Al-Hilyah dari Anas)

Hadits di atas menjelaskan bahwa kemiskinan dapat menjadikan seseorang memiliki penyakit hati seperti tidak mensyukuri nikmat Allah SWT hingga terjerumus pada hal-hal negatif seperti melakukan pencurian, ikut serta dalam permainan judi, dan sebagainya. Oleh sebab itu, Islam mengajarkan kepada manusia untuk selalu menempatkan harta sebagai titipan Allah SWT yang dapat

1] Jurnal ini merupakan bagian dari skripsi dari Elita Sri Arumningtyas, NIM: 04121 1431027, yang diuji pada tanggal 9 Februari 2017 
Arumningtyas, et al/ Jurnal Ekonomi Syariah Teori dan Terapan Vol. 5 No. 2 Februari 2018: 108-

122; DAMPAK PENYALURAN DANA INFAK SEBAGAI MODAL USAHA DALAM PEMBERDAYAAN

EKONOMI ANGGOTA (STUDI KASUS PADA PROGRAM KOMUNITAS USAHA MANDIRI (KUM)

YAYASAN DANA SOSIAL AL-FALAH SURABAYA)

memberikan manfaat bagi masyarakat

sekitarnya, yaitu dengan cara

menyalurkan sebagian harta untuk orang-

orang yang membutuhkan.

Bekerja sebagai pedagang kaki lima (PKL), pedagang rumahan, dan pedagang di pasar tradisional adalah sebagian dari cara masyarakat untuk bertahan hidup dan menghasilkan keuntungan. Cabang usaha-usaha ini dikenal sebagai sektor informal, yaitu "... sektor yang tidak terorganisasi (unorganized), tidak teratur (unregulated), dan kebanyakan legal tetapi tidak terdaftar (unregistered)" (Widodo, 2005: t.h $(\mathrm{m})$. Alasan masyarakat miskin memilih sektor informal sebagai pekerjaan adalah karena terpaksa, ingin mencari rezeki halal, menghidupi keluarga, dan tidak bergantung pada orang lain. Meskipun pada sektor informal dirasa mudah dan membutuhkan modal yang relatif kecil dibandingan dengan sektor formal, hal tersebut masih menjadi kendala utama bagi para pelaku sektor informal dalam menjalankan usahanya.

Kegiatan ekonomi sektor informal di Kota Surabaya berkembang pesat. Fenomena munculnya PKL dapat kita jumpai seperti di jalan Embong Malang sebagai sentra stempel dan plat nomor kendaraan, jalan Semarang sentra PKL kacamata dan buku bekas, jalan Kayun sentra PKL bunga dan ikan hias, dan lianlain. PKL dijadikan sebagai aset kota yang harus diberdayakan. Secara tidak langsung, sektor informal telah meningkatkan taraf hidup masyarakat menjadi lebih baik.

Permodalan menjadi salah satu permasalahan bagi masyarakat yang membutuhkan dana untuk menjalankan usahanya. Selain upaya dari pemerintah, BAZ/LAZ memiliki andil yang besar dalam membantu menangani permasalahan tersebut. Dana ZIS yang diberikan dalam bentuk permodalan akan sangat membantu dalam mengembangkan usaha-usaha golongan ekonomi lemah, khususnya orang-orang yang tidak dapat berusaha secara optimal akibat ketiadaan modal. Mufraini (2008: 154) menjelaskan bahwa "... pola distribusi produktif sangat efektif untuk dapat memproyeksikan perubahan seorang mustahik menjadi muzaki ....". Dengan ini diharapkan pola distribusi produktif dapat membantu mengembangkan usaha mereka dan memenuhi kebutuhan secara terus-menerus.

Komunitas Usaha Mandiri (KUM) merupakan salah satu program kerja unggulan berbasis pemberdayaan ekonomi kota dari Yayasan Dana Sosial alFalah Surabaya. Program ini dilakukan dengan cara menyalurkan bantuan berupa pinjaman modal usaha yang bersumber dari dana infak kepada pengusaha mikro yang telah menjadi anggota binaan program KUM secara bergilir dengan menggunakan akad qardhul hasan atau pinjaman kebajikan. Program KUM tidak hanya sekedar menyalurkan modal, melainkan juga 
Arumningtyas, et al/ Jurnal Ekonomi Syariah Teori dan Terapan Vol. 5 No. 2 Februari 2018: 108-

122; DAMPAK PENYALURAN DANA INFAK SEBAGAI MODAL USAHA DALAM PEMBERDAYAAN EKONOMI ANGGOTA (STUDI KASUS PADA PROGRAM KOMUNITAS USAHA MANDIRI (KUM) YAYASAN DANA SOSIAL AL-FALAH SURABAYA) mengadakan berbagai kegiatan seperti pengajian, pemberian motivasi, dan pembinaan pengembangan usaha mustahik. Penambahan modal usaha ini bukan untuk modal awal, tetapi memberikan solusi bagi pengusaha mikro yang membutuhkan pinjaman modal dalam upaya mengembangkan usaha yang sudah dirintisnya.

Jika penyaluran modal usaha digunakan secara produktif dan tepat, maka akan meningkatkan kemampuan anggota binaan dalam berwirausaha, tingkat pendapatan bertambah, sehingga pada akhirnya kesejahteraan hidup anggota binaan akan meningkat. Hal ini dapat dicapai melalui proses pemberdayaan yang dilakukan secara terus-menerus.

Tujuan akhir proses pemberdayaan ekonomi adalah masyarakat telah berhasil mengubah kondisi usahanya, mampu meningkatkan taraf hidup keluarga, serta dapat mengelola sumber daya yang dimilikinya. Untuk mengetahui hal tersebut, digunakan indikator keberhasilan usaha anggota yang dilihat dari pembandingan sebelum dan sesudah menerima penyaluran modal usaha terhadap peningkatan omset penjualan usaha, laba usaha, dan ketersediaan barang dalam jangka waktu tertentu.

Berdasarkan uraian diatas, maka penulis tertarik meneliti lebih dalam mengenai : "Dampak Penyaluran Dana Infak Sebagai Modal Usaha dalam Pemberdayaan Ekonomi Anggota (Studi Kasus pada Program Komunitas Usaha Mandiri (KUM) Yayasan Dana Sosial alFalah Surabaya)".

Berdasarkan latar belakang permasalahan di atas, maka rumusan masalah yang diangkat dalam penelitian ini yaitu : "Bagaimana dampak penyaluran dana infak sebagai modal usaha dalam memberdayakan ekonomi usaha anggota binaan program Komunitas Usaha Mandiri di Kota Surabaya?"

Penelitian ini ditujukan untuk mengetahui seberapa besar dampak penyaluran dana infak yang dialokasikan sebagai modal usaha dalam memberdayakan ekonomi usaha anggota binaan melalui program Komunitas Usaha Mandiri di Kota Surabaya yang dilihat dari peningkatan omset penjualan usaha, laba usaha, dan ketersediaan barang setelah menerima pinjaman modal usaha.

\section{LANDASAN PUSTAKA}

"Infak berasal dari kata anfaqa yang berarti 'mengeluarkan sesuatu (harta) untuk kepentingan sesuatu'. Menurut terminologi syariat, infak berarti mengeluarkan dari harta atau pendapatan/penghasilan untuk suatu kepentingan yang diperintahkan ajaran Islam" (Hafidhuddin, 1998: 1415).

Allah SWT telah memerintahkan pada manusia agar menafkahkan sebagian harta yang diperoleh dari hasil kerjanya untuk kepentingan umum. Perintah ini telah tertulis dalam firman-Nya QS. AlBaqarah [2]:267 : 
Arumningtyas, et al/ Jurnal Ekonomi Syariah Teori dan Terapan Vol. 5 No. 2 Februari 2018: 108-

122; DAMPAK PENYALURAN DANA INFAK SEBAGAI MODAL USAHA DALAM PEMBERDAYAAN EKONOMI ANGGOTA (STUDI KASUS PADA PROGRAM KOMUNITAS USAHA MANDIRI (KUM) YAYASAN DANA SOSIAL AL-FALAH SURABAYA)

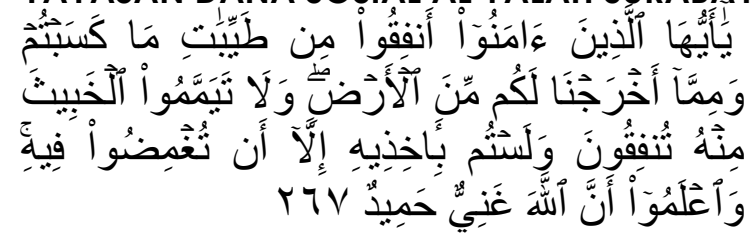

$Y a>$ ayyuha> 'l-laz $\backslash>$ na $\ddot{a}>m a n u>$ anfiqu> min-t\}ayyiba>ti ma> kasabtum wa mimma> akhrajna> lakum-mina 'l-ardi wala> tayammamu> 'l-khabi>tsa-minhu tunfiqu>na wa lastum biä>-khiz $\backslash i>$ hi illa> an-tughmidu> fi>hi, wa 'lamu> anna 'l-La>ha ghaniyyun hami $>d($ un $)$.

"Hai orang-orang yang beriman, nafkahkanlah (di jalan Allah) sebagian dari hasil usahamu yang baik-baik dan sebagian dari apa yang Kami keluarkan dari bumi untuk kamu. dan janganlah kamu memilih yang buruk-buruk lalu kamu menafkahkan daripadanya, Padahal kamu sendiri tidak mau mengambilnya melainkan dengan memicingkan mata terhadapnya. dan ketahuilah, bahwa Allah Maha Kaya lagi Maha Terpuji".

Infak adalah ibadah fardhu kifayah yang dapat dilakukan oleh seluruh umat muslim, baik yang berpenghasilan tinggi maupun rendah, dengan tujuan untuk kepentingan agama. Dana infak " ... dapat membantu mengalirkan kekayaan dari si kaya di dalam masyarakat kepada kaum miskin dan mereka yang memerlukan" (Chaudhry, 2012: 98). Infak boleh dilakukan sewaktu-waktu oleh umat muslim tanpa ada batasan jumlah, jenis barang, dan sasaran yang dituju.

Infak merupakan salah satu instrumen distribusi kekayaan Islami yang dapat membantu mengurangi permasalahan ekonomi, terutama kemiskinan dan kesenjangan sosial yang terjadi di lingkungan masyarakat saat ini.

Kata distribusi memiliki arti "penyaluran (pembagian, pengiriman) kepada beberapa orang atau ke beberapa tempat" (KBBI, "distribusi"). Berbeda dengan dana zakat yang hanya disalurkan kepada delapan asnaf (QS. AtTaubah [9]:60), penyaluran dana infak dapat diberikan kepada orang-orang terdekat di sekitar kita, seperti kedua orang tua dan kerabat, anak yatim, orang miskin, dan orang yang sedang dalam perjalanan (QS. Al-Baqarah [2]:215). Mufraini (2006: 147) menerangkan bahwa inovasi distribusi ZIS dikategorikan dalam empat macam, yaitu:

1. Distribusi bersifat 'konsumtif tradisional', yaitu zakat dibagikan kepada mustahik untuk dimanfaatkan secara langsung, seperti zakat fitrah yang diberikan kepada fakir miskin.

2. Distribusi bersifat 'konsumtif kreatif', yaitu zakat diwujudkan dalam bentuk lain dari barangnya semula, seperti diberikan dalam bentuk alatalat sekolah atau beasiswa.

3. Distribusi bersifat 'produktif tradisional', dimana zakat diberikan dalam bentuk barang-barang yang produktif seperti kambing, sapi, alat cukur, dan lain sebagainya. Pemberian dalam bentuk ini akan dapat menciptakan suatu usaha yang membuka lapangan kerja bagi fakir miskin.

4. Distribusi dalam bentuk 'produktif kreatif', yaitu zakat diwujudkan dalam bentuk permodalan baik untuk membangun proyek sosial atau menambah modal pedagang pengusaha mikro.

Pengelolaan dana infak tidak berbeda jauh dengan pengelolaan zakat. Penyaluran dana infak, baik secara konsumtif dan produktif, diharapkan dapat meningkatkan taraf hidup masyarakat, menumbuhkan kemampuan 
Arumningtyas, et al/ Jurnal Ekonomi Syariah Teori dan Terapan Vol. 5 No. 2 Februari 2018: 108-

122; DAMPAK PENYALURAN DANA INFAK SEBAGAI MODAL USAHA DALAM PEMBERDAYAAN EKONOMI ANGGOTA (STUDI KASUS PADA PROGRAM KOMUNITAS USAHA MANDIRI (KUM) YAYASAN DANA SOSIAL AL-FALAH SURABAYA)

untuk berinfak, dan mengurangi

kesenjangan antara si kaya dan si miskin dan terciptanya pemerataan distribusi pendapatan dan hubungan harmonis antara individu dengan individu lainnya.

Pada umumnya, dana yang didistribusikan secara produktif, yaitu sebagai modal usaha, dikembangkan dengan menggunakan akad qardhul hasan. Perwataatmadja dan Antonio (1993: 33) menjelaskan :

"Al Qardhul Hasan atau Benevolent Loan adalah suatu pinjaman lunak yang diberikan atas dasar kewajiban sosial semata dimana si peminjam tidak dituntut untuk mengembalikan apapun kecuali pinjaman".

Akad ini seringkali dipergunakan dalam pembiayaan bank syariah, penyaluran modal usaha yang dilakukan BAZ/LAZ, dan lembaga keuangan syariah lainnya. Hal ini bertujuan untuk memberikan kemudahan kepada orang-orang yang membutuhkan dana untuk keperluan konsumtif jangka pendek maupun tambahan modal usaha.

Landasan syariah mengenai pemberian pinjaman tunai qardhul hasan telah dijelaskan dalam QS. Al-Baqarah [2]: 245 sebagai berikut :

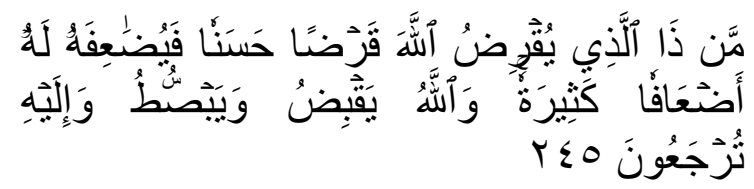

Man-zla 'l-lazli> yuqridu 'l-La>ha qarda>n hasana $>n$ fayuda $>$ 'ifahu>lahu> ad-' $a>f a>n$ katsi>ratan, wa 'l-La>hu yuqbidu wayabsut\}u wa-ilaihi turja ' $u>n(a)$.

"Siapakah yang mau memberi pinjaman kepada Allah, pinjaman yang baik (menafkahkan hartanya di jalan Allah),

maka Allah akan meperlipat gandakan pembayaran kepadanya dengan lipat ganda yang banyak. Dan Allah menyempitkan dan melapangkan (rezeki) dan kepada-Nya-lah kamu dikembalikan".

Qardhul hasan dapat digunakan untuk kepentingan umum yang bermanfaat bagi masyarakat, terutama kepada para pengusaha mikro yang kekurangan dana dan mempunyai prospek bisnis yang cukup baik. Oleh sebab itu, melalui prinsip ini diharapkan dapat memberikan kemudahan bagi mereka dalam mendapatkan pinjaman modal usaha yang diperbolehkan syariat Islam.

Di bawah ini disampaikan bentuk pola distribusi produktif yang mengedepankan skema qardhul hasan diilustrasikan sebagai berikut :

Keterangan :

1. Muzaki membayar zakat kepada BAZ/LAZ;

2. BAZ/LAZ menyalurkan kepada mustahik । untuk dimanfaatkan sebagai modal usaha;

3. Usaha untung maka mustahik

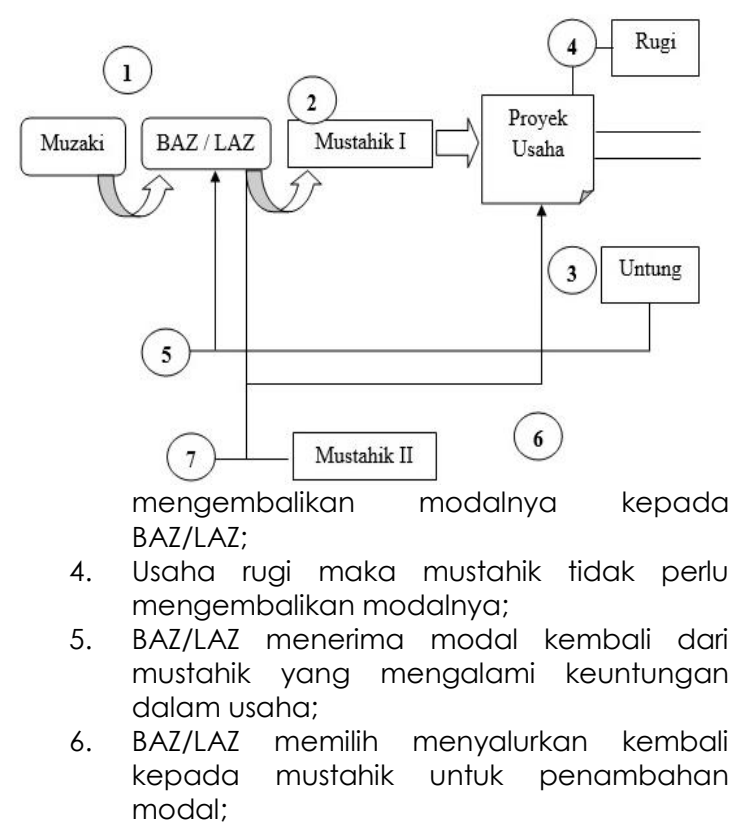


Arumningtyas, et al/ Jurnal Ekonomi Syariah Teori dan Terapan Vol. 5 No. 2 Februari 2018: 108-

122; DAMPAK PENYALURAN DANA INFAK SEBAGAI MODAL USAHA DALAM PEMBERDAYAAN

EKONOMI ANGGOTA (STUDI KASUS PADA PROGRAM KOMUNITAS USAHA MANDIRI (KUM)

YAYASAN DANA SOSIAL AL-FALAH SURABAYA)

7. BAZ/LAZ memilih menyalurkan kepada mustahik II untuk dimanfaatkan sebagai modal usaha ... dan begitu seterusnya.

Sumber : Mufraini, M. Arief. 2006. Akuntansi dan Manajemen Zakat : Mengkomunikasikan Kesadaran dan Mengembangkan Jaringan. Jakarta: Kencana.

\section{Gambar 2.1}

Skema Pinjaman Qardhul Hasan

Usaha mikro menjadi sasaran utama yang diperhatikan oleh BAZ/LAZ dalam distribusi produktif. Secara umum, usaha mikro tidak memiliki struktur organisasi formal, dimiliki oleh keluarga, dan menggunakan teknologi sederhana. Melalui suatu program kerja yang telah disusun secara terstruktur dan dengan upaya pemberdayaan ekonomi usaha dari pengelola zakat, diharapkan para pelaku usaha mikro lebih giat dalam bekerja, termotivasi untuk mencari rezeki halal, gemar bersedekah, serta mengamalkan nilai-nilai Islam dalam kehidupan sehari-hari.

Pemberdayaan adalah proses yang dilakukan suatu lembaga yang mempunyai kepentingan untuk meningkatkan kualitas hidup kelompok masyarakat miskin mulai dari keterampilan, pengetahuan dan kekuasaan sehingga memberikan wadah untuk menyuarakan pendapat atau gagasan secara luas. Hal ini dapat dilakukan dengan memberikan modal usaha dan keterampilan tertentu sesuai dengan potensi yang tersedia di lingkungan sekitarnya.

Salah satu instrumen pemberdayaan ekonomi masyarakat dalam Islam adalah

menggunakan zakat, infak, dan sedekah. Ketiga instrumen tersebut mampu mengurangi kesenjangan sosial yang terjadi di lingkungan masyarakat dan meningkatkan kemampuan daya beli masyarakat miskin, baik berupa barang maupun jasa. Dana infak memiliki pengaruh besar terhadap pembentukan modal guna meningkatkan kualitas sumber daya manusia dan penyedia sarana prasarana produksi.

$$
\text { Menurut Guntur (2009: }
$$

menjelaskan :
"Konsep keterberdayaan pada dasarnya adalah upaya menjadikan suasana kemanusiaan yang adil dan beradab yang semakin efektif secara struktural dalam bidang ... ekonomi yang baik di dalam kehidupan kelvarga, masyarakat, negara, ....".

Artinya, seseorang atau masyarakat yang teberdayakan akan dapat mengembangkan diri untuk mencapai kemajuan usaha. Riyanti (2003: 28) dalam Pamungkas (2014: 20) menjelaskan :

"indikator keberhasilan usaha terdiri dari : 1) Meningkatnya omset; 2) Bertambahnya jumlah karyawan; 3) Meningkatnya volume penjualan; dan 4) Meningkatnya jumlah pelanggan dan transaksi".

Selanjutnya, Nuritha et al (2013: 2) menyatakan bahwa "... untuk mengukur keberhasilan usaha berdasarkan tingkat kedatangan pelanggan, pertumbuhan laba bersih, ....". Sesuai dengan tujuan penelitian, pengukuran keberhasilan usaha dilihat dari peningkatan omset penjualan usaha, laba usaha, dan ketersediaan barang. 
Arumningtyas, et al/ Jurnal Ekonomi Syariah Teori dan Terapan Vol. 5 No. 2 Februari 2018: 108-

122; DAMPAK PENYALURAN DANA INFAK SEBAGAI MODAL USAHA DALAM PEMBERDAYAAN EKONOMI ANGGOTA (STUDI KASUS PADA PROGRAM KOMUNITAS USAHA MANDIRI (KUM) YAYASAN DANA SOSIAL AL-FALAH SURABAYA)

Menurut Nurfitria (2011: 10)

menjelaskan omset penjualan adalah "... keseluruhan jumlah penjualan barang/jasa dalam kurun waktu tertentu, yang dihitung berdasarkan jumlah vang yang diperoleh". Omset menjadi penentu seberapa besar pemasukan yang diperoleh dari hasil penjualan. Omset yang tinggi akan membuat para pengusaha lebih banyak kemungkinan memperoleh keuntungan dan dapat digunakan untuk memenuhi kebutuhan sehari-hari. Apabila omset menurun, maka pengusaha tidak dapat memperoleh hasil yang optimal.

Kedua, laba diartikan sebagai "kelebihan pendapatan dibandingkan dengan jumlah biaya yang dikeluarkan untuk memperoleh pendapatan tersebut (profit)" (Kamus-Bank Sentral Republik Indonesia, "laba"). Semakin tinggi laba yang diperoleh, diharapkan usaha tersebut akan mampu bertahan hidup, tumbuh, dan berkembang dalam menghadapi persaingan.

Ketiga, ketersediaan barang menjadi hal yang penting dalam kegiatan berwirausaha. Salah satu kriteria untuk menyatakan keberhasilan suatu usaha adalah apabila barang yang ia perdagangkan terjual habis, maka ia akan menambah sediaan barang tersebut lebih banyak agar menambah pemasukan usahanya. Hal ini membuat perputaran vang di dalam usaha tersebut selalu berjalan dan menghasilkan keuntungan yang lebih besar.

\section{METODOLOGI PENELITIAN}

Moleong (2010: 6) menjelaskan definisi penelitian kualitatif sebagai berikut :

" ...penelitian kualitatif adalah penelitian yang bermaksud untuk memahami fenomena tentang apa yang dialami oleh subjek penelitian misalnya perilaku, persepsi, motivasi, dan tindakan, dll., secara holistik, dan dengan cara deskripsi dalam bentuk kata-kata dan bahasa, pada suatu konteks khusus yang alamiah dan dengan memanfaatkan berbagai metode alamiah.

Hasil penelitian ini tidak dapat digeneralisasikan, karena penelitian ini hanya berfokus pada salah satu program kerja yang diselenggarakan oleh satu lembaga pengelola zakat, yaitu program Komunitas Usaha Mandiri dari Yayasan Dana Sosial al-Falah Surabaya.

Konsep studi kasus Yin dipilih sebagai metode penelitian yang paling sesuai untuk membantu menghasilkan jawaban penelitian secara sistematik, akurat, dan sesuai dengan tujuan penelitian. Pertama, metode studi kasus bertujuan untuk menjawab pertanyaan "bagaimana" atau "mengapa" yang hanya dapat ditemukan jawabannya melalui pengamatan yang mendalam. Hal ini sesuai dengan rumusan masalah yang telah disusun sebelumnya.

Kedua, penelitian ini hanya memiliki peluang yang sangat kecil untuk melakukan kontrol terhadap peristiwa tersebut, sehingga hasil penelitian tidak bisa atau sulit untuk dimanipulasi oleh peneliti. Dan terakhir, rumusan masalah yang diangkat dalam sebuah penelitian 
Arumningtyas, et al/ Jurnal Ekonomi Syariah Teori dan Terapan Vol. 5 No. 2 Februari 2018: 108-

122; DAMPAK PENYALURAN DANA INFAK SEBAGAI MODAL USAHA DALAM PEMBERDAYAAN

EKONOMI ANGGOTA (STUDI KASUS PADA PROGRAM KOMUNITAS USAHA MANDIRI (KUM)

YAYASAN DANA SOSIAL AL-FALAH SURABAYA)

didasarkan pada peristiwa atau

permasalahan yang terjadi pada

lingkungan masyarakat saat ini.

Penelitian ini menggunakan strategi studi kasus deskriptif, artinya memberi gambaran terhadap subjek/objek yang diteliti melalui data atau sampel yang telah ditetapkan, tanpa melakukan analisis yang membuat kesimpulan yang berlaku untuk umum. Pemilihan metode penelitian harus dilakukan dengan tepat agar hasil penelitian yang didapat sesuai dengan tujuan penelitian.

Selanjutnya, penelitian ini menggunakan desain studi kasus yang dirancang oleh Yin (1988: 29) sebagai berikut :

1. A study's questions

Pertanyaan penelitian menjadi aspek penentuan dalam memilih strategi penelitian yang akan digunakan. Penelitian ini menggunakan strategi studi kasus deskriptif karena pertanyaan penelitian yang digunakan adalah "Bagaimana dampak penyaluran dana infak sebagai modal usaha dalam memberdayakan ekonomi usaha anggota binaan program Komunitas Usaha Mandiri di Kota Surabaya?".

\section{Propositions}

Yin (1988: 30) menjelaskan "... each proposition direct attention to something that should be examined within the scope of study". Proposisi yang digunakan dalam penelitian ini adalah "Dana infak yang dialokasikan

sebagai modal usaha akan mampu memberikan manfaat bagi keberlangsungan ekonomi usaha, khususnya pada usaha anggota binaan program Komunitas Usaha Mandiri yang berlokasi di Kota Surabaya yang kemudian menjadikan keberlangsungan usaha tersebut semakin baik dan produktif.

3. Unit(s) of analysis

Unit analisis adalah hal yang berkaitan dengan penentuan aspek apa saja yang diteliti sesuai proposisi yang telah dirancang sebelumnya. Sebagai pedoman untuk mencari data tersebut, digunakan research questions sebagai berikut :

1) Bagaimana kondisi usaha yang Anda jalani setelah menerima pinjaman modal usaha dari program KUM YDSF Surabaya?

2) Apakah omset penjualan usaha Anda meningkat setelah menerima pinjaman modal usaha KUM?

3) Apakah laba usaha Anda meningkat setelah menerima pinjaman modal usaha KUM?

4) Apakah ada penambahan barang (dagangan) setelah menerima pinjaman modal usaha KUM?

5) Apakah Anda menyisihkan sebagian hasil usaha untuk berinfak?

6) Apakah Anda merasakan manfaatnya dari keikutsertaan Anda dalam program YDSF?

Ruang lingkup penelitian ini berkaitan dengan rumusan masalah yang telah ditentukan sebelumnya. Pertama, terbatas pada mustahik yang menjadi anggota binaan program KUM yang diselenggarakan oleh YDSF yang berlokasi 
Arumningtyas, et al/ Jurnal Ekonomi Syariah Teori dan Terapan Vol. 5 No. 2 Februari 2018: 108-

122; DAMPAK PENYALURAN DANA INFAK SEBAGAI MODAL USAHA DALAM PEMBERDAYAAN EKONOMI ANGGOTA (STUDI KASUS PADA PROGRAM KOMUNITAS USAHA MANDIRI (KUM) YAYASAN DANA SOSIAL AL-FALAH SURABAYA)

di Kota Surabaya. Kedua, keberhasilan usaha anggota binaan dilihat dari pembandingan sebelum dan sesudah menerima penyaluran pinjaman modal usaha terhadap peningkatan omset penjualan usaha, laba usaha, serta ketersediaan barang dalam jangka waktu tertentu. Ketiga, hasil penelitian ini tidak dapat digeneralisasikan, baik kepada mustahik lain maupun kepada waktu lain.

Proses pengumpulan data merupakan langkah yang paling utama dalam menemukan hasil penelitian. Pada penelitian ini, dipilih teknik pengumpulan data observasi langsung, wawancara, dan dokumentasi karena diharapkan untuk mendapatkan data yang berkualitas baik dan sesuai dengan kebutuhan penelitian.

Pemeriksaan keabsahan pada data yang telah diperoleh selama proses pengumpulan data perlu diperhatikan. Pada penelitian ini, teknik yang digunakan adalah teknik triangulasi sumber, yaitu membandingkan atau mengecek keselarasan antara hasil wawancara dengan pihak terkait, hasil observasi, dan hasil dokumentasi yang didapat selama proses pengumpulan data. Teknik ini dipilih sebagai uji keabsahan data yang paling sesuai untuk membantu menghasilkan jawaban penelitian yang sahih dan dapat dipertanggungjawabkan dari segala segi.

Tahap terakhir dari serangkaian metodologi penelitian adalah teknik analisis. Proses analisis data sudah dilakukan pada saat pengumpulan data

berlangsung dan setelah selesai pengumpulan data dalam periode tertentu. Sugiyono (2009: 431-438) menerangkan terdapat tiga aktivitas dalam analisis data, yaitu data reduction atau memilih dan merangkum data yang dianggap sesuai dengan tujuan penelitian. Kedua, data display, yaitu menguraikan hasil penelitian berdasarkan fakta yang terjadi di lokasi penelitian dalam bentuk tulisan. Dan terakhir, conclusion drawing/verification, adalah rangkaian kalimat atau pernyataan berisi pendapat dan fakta terpenting mengenai suatu permasalahan. Kesimpulan dalam penelitian kualitatif diharapkan dapat menjawab rumusan masalah yang telah dirumuskan sejak awal dan menghasilkan temuan baru yang sebelumnya belum pernah ada.

\section{Hasil dan Pembahasan}

Komunitas Usaha Mandiri merupakan salah satu program kerja unggulan berbasis pemberdayaan ekonomi dari Yayasan Dana Sosial al-Falah Surabaya yang sudah berjalan sejak tahun 2010. Program ini melakukan penyaluran bantuan berupa pinjaman modal usaha yang bersumber dari dana infak secara bergilir kepada pengusaha mikro yang telah menjadi anggota binaan dengan menggunakan akad qardhul hasan atau pinjaman kebajikan. Sumber dana diperoleh dari dana infak yang dikeluarkan oleh para donatur rutin YDSF Surabaya. Dana infak yang terkumpul kemudian dibagi dan disalurkan pada 
Arumningtyas, et al/ Jurnal Ekonomi Syariah Teori dan Terapan Vol. 5 No. 2 Februari 2018: 108-

122; DAMPAK PENYALURAN DANA INFAK SEBAGAI MODAL USAHA DALAM PEMBERDAYAAN EKONOMI ANGGOTA (STUDI KASUS PADA PROGRAM KOMUNITAS USAHA MANDIRI (KUM) YAYASAN DANA SOSIAL AL-FALAH SURABAYA) masing-masing program kerja di bidang pendidikan, yatim, dakwah, dan masjid sesuai persentase yang telah ditentukan.

Ada beberapa syarat bagi mustahik yang harus dipenuhi dalam mengajukan pinjaman modal usaha. Syarat yang telah ditetapkan harus dipenuhi oleh calon anggota binaan program KUM sebagai berikut :

1. Orang yang kurang mampu

Yang dimaksud dengan orang yang kurang mampu adalah orang yang memiliki penghasilan yang sangat kecil dan hidup dalam keadaan ekonomi yang lemah.

2. Orang yang memiliki usaha mikro yang dapat dikembangkan

Sebelum mengajukan bantuan modal maka orang tersebut harus memiliki usaha mikro yang memiliki potensi untuk dikembangkan.

3. Orang yang bersedia untuk dibina dan mengikuti serangkaian kegiatan rutin program KUM

Calon anggota binaan diharuskan mengikuti serangkaian kegiatan dan pelatihan yang diadakan oleh pengurus program KUM.

Semua jenis usaha dapat diajukan untuk mendapatkan bantuan pinjaman, asalkan usaha tersebut merupakan usaha berskala mikro seperti pracangan, pedagang buah, pedagang mainan anak, dan sebagainya.

Prosedur penyaluran pinjaman modal usaha kepada anggota binaan program KUM dilakukan sesuai dengan tahapannya. Gambar di bawah ini diharap dapat menjelaskan.

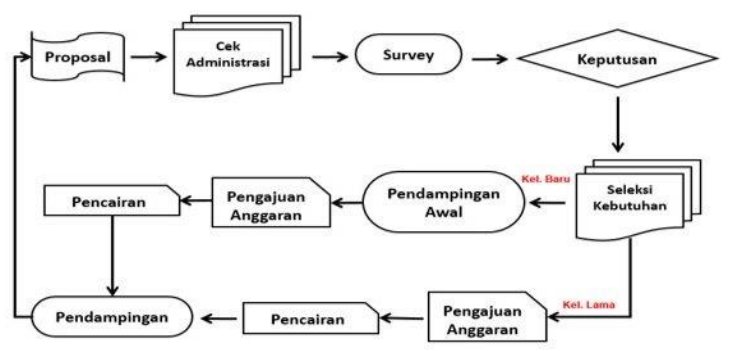

Sumber : Mekanisme Proses Pinjaman Program Komunitas Usaha Mandiri, 2016.

Gambar 4.1

Prosedur Penyaluran Modal Usaha

Program Komunitas Usaha Mandiri

Langkah pertama dimulai dari pengisian formulir pengajuan bantuan yang tersedia di Kantor Pendayagunaan YDSF Surabaya dengan melampirkan fotokopi kartu keluarga, fotokopi KTP, dan surat keterangan domisili. Dari pengajuan tersebut akan dilakukan pengecekan oleh pengurus terkait kelengkapan berkasberkas dan kriteria usaha yang layak dibantu. Selanjutnya, tim lapangan program KUM melakukan survey di lokasi usaha calon anggota binaan. Saat di lokasi, tim lapangan mengamati karakter personal mustahik, kondisi perekonomian, dan prospek usaha ke depan. Dari hasil survey tersebut akan dilakukan musyawarah bersama dengan pengurus lain untuk memutuskan apakah usaha mustahik tersebut layak dibantu dan bergabung dalam program KUM.

Pengajuan permohonan pinjaman dapat dilakukan perorangan, asalkan orang tersebut sudah ada yang membawahi atau tergabung dalam satu komunitas yang sudah berdiri di sekitar 
Arumningtyas, et al/ Jurnal Ekonomi Syariah Teori dan Terapan Vol. 5 No. 2 Februari 2018: 108-

122; DAMPAK PENYALURAN DANA INFAK SEBAGAI MODAL USAHA DALAM PEMBERDAYAAN EKONOMI ANGGOTA (STUDI KASUS PADA PROGRAM KOMUNITAS USAHA MANDIRI (KUM) YAYASAN DANA SOSIAL AL-FALAH SURABAYA)

pemukimannya. Selain itu, dapat juga

dilakukan oleh beberapa orang yang hendak membentuk komunitas baru. Satu komunitas terdiri dari minimal lima calon anggota binaan.

Tahap selanjutnya dilakukanseleksi kebutuhan, yaitu pengurus merancang kegiatan atau pelatihan apa saja yang dibutuhkan oleh komunitas baru berdasarkan hasil survey. Hal ini bertujuan untuk menjadikan calon anggota binaan memperoleh pengetahuan ilmu agama dan kemampuan wirausaha lebih mendalam. Bagi komunitas lama, seleksi kebutuhan dilakukan setiap semester untuk memperbarui kegiatan dan pelatihan sesuai hasil survey. Sebelum bantuan pinjaman dicairkan, dilakukan pendampingan awal kepada calon anggota binaan, yaitu memperkenalkan seluk-beluk program KUM. Untuk pengajuan pertama, calon anggota binaan menerima pinjaman modal usaha sebesar Rp 1.000.000,- dengan angsuran sesuai kesepakatan kedua belah pihak.

Pada saat pencairan pinjaman, pengurus akan memberikan penjelasan mengenai pinjaman akad qardhul hasan kepada calon anggota binaan sesuai yang tertera pada surat akad pinjaman. Hal ini dilakukan sebagai rukun dan syarat sah sebuah akad yang harus dipenuhi. Selanjutnya, calon anggota binaan menandatangani akad yang disaksikan oleh pengurus program KUM dan disahkan sebagai anggota binaan program KUM. Anggota binaan dapat mulai menggunakan dan memanfaatkan modal usaha secara proporsional serta mengikuti berbagai kegiatan yang diadakan oleh komunitas maupun pengurus. Apabila ada anggota binaan yang telah melunasi angsuran dan hendak melakukan pinjaman kembali, mereka dapat mengajukan permohonan pinjaman seperti yang telah dilakukan sebelumnya.

Berdasarkan penelitian yang telah dilakukan dan ruang lingkup penelitian yang digunakan dalam penulisan skripsi ini, maka hasil penelitian hanya akan membahas dampak atau pembandingan sebelum dan sesudah menerima penyaluran pinjaman modal usaha yang dilihat dari omset penjualan usaha, laba usaha, serta ketersediaan barang dalam jangka waktu tertentu yang dirasakan oleh anggota binaan program KUM. Wawancara dilakukan kepada empat anggota binaan program KUM melalui teknik purposive sampling dan dipilih dari empat komunitas secara acak yang ada di wilayah Kota Surabaya.

Di bawah ini disampaikan hasil rangkuman yang telah diolah dari proses pengumpulan data dengan informan sebagai berikut :

\section{Peningkatan Omset Penjualan Usaha}

Omset menjadi penentu seberapa besar pemasukan yang diperoleh dari hasil penjualan. Omset yang tinggi akan membuat para pengusaha lebih banyak kemungkinan memperoleh keuntungan dan dapat digunakan 
Arumningtyas, et al/ Jurnal Ekonomi Syariah Teori dan Terapan Vol. 5 No. 2 Februari 2018: 108-

122; DAMPAK PENYALURAN DANA INFAK SEBAGAI MODAL USAHA DALAM PEMBERDAYAAN EKONOMI ANGGOTA (STUDI KASUS PADA PROGRAM KOMUNITAS USAHA MANDIRI (KUM) YAYASAN DANA SOSIAL AL-FALAH SURABAYA)

untuk memenuhi kebutuhan sehari-hari.

Apabila omset menurun, maka pengusaha tidak dapat memperoleh hasil yang optimal. Pada penelitian ini, omset penjualan menjadi indikator utama dalam menentukan apakah usaha yang dimiliki keempat informan tersebut berhasil atau tidak.

Hasil penelitian menunjukkan bahwa omset penjualan usaha yang diperoleh dari hasil penjualan mengalami peningkatan, meskipun tidak dapat disebutkan berapa besaran omset yang diterima secara nominal. Dikatakan bahwa peningkatan tersebut tidak naik secara tajam, namun keempat informan merasakan adanya perubahan kondisi perekonomian keluarga menjadi lebih baik jika dibandingan dengan sebelumnya. Sebagian hasil penjualan tersebut mereka gunakan untuk melunasi utang-utang yang masih ada, membantu suami dalam membiayai sekolah anak-anak mereka, dan memiliki kemampuan untuk berinfak dan menabung. Perolehan omset lainnya akan mereka putar untuk mencukupi kebutuhan usahanya.

Sampai saat ini, usaha yang mereka jalankan terus mengalami perkembangan baik dilihat dari bertambahnya pelanggan maupun meingkatnya barang dagangan mereka. Dengan demikian, pada indikator omset penjualan usaha dapat disimpulkan bahwa keempat informan menerima manfaat dan berhasil teberdayakan dari adanya upaya pemberdayaan oleh program KUM.

\section{Peningkatan Laba Usaha}

Selanjutnya, indikator keberhasilan usaha yang kedua dilihat dari peningkatan laba usaha. Laba diperoleh setelah dikurangi biaya produksi, seperti biaya transportasi, biaya bahan bakar gas, upah pekerja, dan sebagainya. Laba usaha menjadi indikator keberhasilan yang bertujuan mengukur seberapa jauh perkembangan usaha mikro tersebut.

Hasil penelitian menunjukkan bahwa keempat informan tidak dapat menyebutkan berapa besaran laba yang diperoleh secara nominal. Diakui bahwa mereka tidak memiliki catatan keuangan usahanya, sehingga tidak mengetahui secara pasti berapa besaran laba yang diterima. Mereka mengatakan perkiraan laba usaha saat ini sedikit meningkat daripada sebelumnya. Mereka merasakan usaha yang sudah dirintis sejak lama tetap berjalan lancar meskipun sudah banyak usaha-usaha modern (seperti minimarket, toko roti, dan sebagainya) di sekitar lokasi usahanya. Usaha mereka tetap ramai pembeli meskipun sebagian di antara mereka ada yang berutang atau masih menunggak.

Sangat disayangkan bahwa keempat informan tidak mengetahui secara pasti berapa laba bersih yang mereka peroleh dari hasil penjualan, 
Arumningtyas, et al/ Jurnal Ekonomi Syariah Teori dan Terapan Vol. 5 No. 2 Februari 2018: 108-

122; DAMPAK PENYALURAN DANA INFAK SEBAGAI MODAL USAHA DALAM PEMBERDAYAAN

EKONOMI ANGGOTA (STUDI KASUS PADA PROGRAM KOMUNITAS USAHA MANDIRI (KUM)

YAYASAN DANA SOSIAL AL-FALAH SURABAYA)

sehingga tidak bisa dijelaskan

perolehan laba bersih secara angka.

Mereka hanya dapat menyatakan

bahwa setiap pemasukan yang

diterimanya, termasuk laba usaha,

kemudian dikelola dan diputar kembali

untuk kebutuhan usahanya.

\section{Peningkatan Ketersediaan Barang}

Telah dijelaskan pada bab 2 bahwa salah satu indikator keberhasilan usaha menurut Riyanti (2003: 28) dalam Pamungkas (2014: 20) adalah meningkatnya volume penjualan. "Volume penjualan merupakan sesuatu yang menandakan naik turunnya penjualan dan dapat dinyatakan dalam bentuk unit, kilo, ton atau liter" (Rangkuti, 2009: 207 dalam Musdilawati, 2014: 4). Volume penjualan bisa diartikan sebagai tingkat keberhasilan penjualan produk pada waktu tertentu oleh pengusaha. Apabila barang yang ia perdagangkan terjual habis, maka ia akan menambah sediaan barang tersebut lebih banyak agar menambah pemasukan usahanya. Hal ini membuat perputaran vang di dalam usaha tersebut selalu berjalan dan menghasilkan keuntungan yang lebih besar.

Hasil penelitian menunjukkan bahwa keempat informan mengalami penambahan pelanggan pada usahanya, sehingga mereka selalu menambah barang dagangan menjadi lebih banyak dari sebelumnya. Hal ini berlaku pada usaha informan yang berjualan makanan, terkecuali pracangan.

Hampir setiap hari dagangan mereka selalu habis tidak tersisa, bahkan di antara mereka ada yang mendapatkan pesanan dari pembeli. Untuk melayani naiknya volume penjualan itu, mereka menambah jumlah porsi makanan yang dijual agar menghasilkan keuntungan yang lebih besar. Untuk pracangan, barang dagangan yang selalu habis adalah beras, telur, minyak goreng, bumbu dapur, rokok, dan makanan instan seperti mie rebus, mie goreng, serta snack.

Dengan demikian, keempat informan mengalami peningkatan ketersediaan barang pada usahanya. Mereka mengatakan bahwa pinjaman modal usaha yang diterima dari program KUM sangat membantu mereka untuk mengembangkan usahanya lebih baik dari sebelumnya.

\section{SIMPULAN}

Hasil penelitian menunjukkan keempat informan mengalami peningkatan omset penjualan usaha, laba usaha, dan ketersediaan barang setelah menerima pinjaman modal usaha dari program KUM. Meskipun tidak seberapa, mereka merasakan adanya perubahan pada kondisi perekonomian keluarga yang lebih baik dari sebelumnya. Mereka merasakan manfaat dari kegiatan rutin dan pelatihan yang diselenggarakan oleh pengurus KUM. 
Arumningtyas, et al/ Jurnal Ekonomi Syariah Teori dan Terapan Vol. 5 No. 2 Februari 2018: 108-

122; DAMPAK PENYALURAN DANA INFAK SEBAGAI MODAL USAHA DALAM PEMBERDAYAAN EKONOMI ANGGOTA (STUDI KASUS PADA PROGRAM KOMUNITAS USAHA MANDIRI (KUM) YAYASAN DANA SOSIAL AL-FALAH SURABAYA)

Dengan demikian, dapat disimpulkan

bahwa pemberdayaan ekonomi yang dilakukan program KUM melalui penyaluran modal usaha dari dana infak telah memberikan dampak yang besar bagi perkembangan usaha anggota binaan.

\section{DAFTAR PUSTAKA}

Arikunto, Suharsimi. 2005. Manajemen Penelitian. Jakarta: PT. Rineka Cipta.

Chaudhry, Muhammad Sharif. Tanpa Tahun. Sistem Ekonomi Islam : Prinsip Dasar. Terjemahan oleh Suherman Rosyidi. 2012. Jakarta: Kencana Prenada Media Group.

Guntur, Effendi M. 2009. Pemberdayaan Ekonomi Rakyat: Transformasi Perekonomian Rakyat Menuju Kemandirian dan Keadilan. Jakarta: CV. Sagung Seto.

Hafidhuddin, Didin. 1998. Panduan Praktis tentang Zakat, Infak, dan Sedekah. Jakarta: Gema Insani Press.

Mufraini, M. Arief. 2006. Akuntansi dan Manajemen Zakat: Mengkomunikasikan Kesadaran dan Membangun Jaringan. Jakarta: Kencana.

2008. Akuntansi dan Manajemen Zakat: Mengkomunikasikan Kesadaran dan Membangun Jaringan. Jakarta: Kencana.

Moleong, Lexy J. 2010. Metodologi Penelitian Kualitatif. Edisi Revisi. Bandung: Remaja Rosda Karya.

Musdilawati, Ajeng. 2014. Pengaruh Harga Jual dan Biaya Promosi terhadap Volume Penjualan (Studi Kasus pada PT. Kertas Padalarang Persero) (http://elib.unikom.ac.id/gdl.php?mo $d=$ browse\&op=read\&id=jbptunikomp pgdl-ajengmusdi-

34364\&q=musdilawati,

diakses tanggal 17 Januari 2017).

Nurfitria, Nissa. 2011. Analisis Perbedaan Omzet Penjualan Berdasarkan Jenis Hajatan dan Waktu (Studi pada Catering Sonokembang Semarang). Skripsi tidak diterbitkan. Semarang Ekonomi Universitas Diponegoro.

Nuritha, Ifrina et al. 2013. Identifikasi Pengaruh Lokasi Usaha Terhadap Tingkat Keberhasilan Usaha Minimarket Waralaba di Kabupaten Jember dengan Sistem Informasi Geografis. Jurnal Sainstek UNEJ 2013, I (1): 825-835.

Pamungkas, Rizki. 2014. Faktor-faktor yang Mempengaruhi Keberhasilan Usaha Pemegang Usaha Waralaba (Studi Kasus pada Waralaba Makanan dan Minuman Lokal di Kota Semarang). Skripsi tidak diterbitkan. Semarang Ekonomi Universitas Diponegoro.

Perwataatmadja, Karnaen dan Muhammad Syafi'i Antonio. 1993. Apa dan Bagaimana Bank Islam. Yogyakarta: PT. Dana Bhakti Wakaf.

Sugiyono. 2009. Metode Penelitian Bisnis (Pendekatan Kuantitatif, Kualitatif, dan R\&D). Bandung: Penerbit Alfabeta.

Widodo, Tri. 2005. Sektor Informal Yogyakarta. Makalah disajikan dalam Diskusi yang digelar oleh Pusat Studi Ekonomi dan Kebijakan Publik (PSEKP). Yogyakarta.

Yayasan Dana Sosial al-Falah Surabaya. Tanpa Tahun. Data Keuangan Pengelolaan dan Mekanisme Proses Pinjaman Program Komunitas Usaha Mandiri. Data diperoleh dari pengurus program Komunitas Usaha Mandiri, data tidak dipublikasikan.

Yin, Robert K. 1988. Case Study Research Design and Methods (Applied Social Research Methods Series). Vol. 5 Revised Edition. London: SAGE Publications. 